\title{
Abundance, color pattern variation, life cycle, and reproduction of the triploid parthenogenetic lizard Aspidoscelis uniparens (Squamata: Teiidae) in Chihuahua, Mexico
}

\author{
James M. Walker, ${ }^{1}$ Julio A. Lemos-Espinal, ${ }^{2}$ James E. Cordes, ${ }^{3}$ and Hobart M. Smith $^{4}$ \\ ${ }^{1}$ Department of Biological Sciences, University of Arkansas, Fayetteville, Arkansas 72701 USA. E-mail: jmwalker@uark.edu. \\ ${ }^{2}$ Laboratorio de Ecología, UBIPRO, Facultad de Estudios Superiores Iztacala, Av. Los Barrios 1, Los Reyes Iztacala, \\ Tlalnepantla, Estado de México, 54090, Mexico. E-mail: lemos@unam.mx. \\ ${ }^{3}$ Division of Sciences and Mathematics Louisiana State University Eunice, Eunice, Louisiana 70535, USA. E-mail: jcordes@ \\ lsue.edu. \\ ${ }^{4}$ University of Colorado Museum of Natural History, Boulder, Colorado 80309, USA.
}

\begin{abstract}
Abundance, color pattern variation, life cycle, and reproduction of the triploid parthenogenetic lizard Aspidoscelis uniparens (Squamata: Teiidae) in Chihuahua, Mexico. We have observed the triploid parthenogenetic lizard Aspidoscelis uniparens in syntopy with many congeners, as well as allopatric to them, within a distribution area in parts of Arizona, New Mexico, and Texas (USA), and Chihuahua and Sonora (Mexico). In July 2000, we discovered arrays (= groups) of A. uniparens with distinctive dorsal color patterns, allopatric to congeners, at a cluster of three sites in northwestern Chihuahua. These arrays were distinguishable based on strikingly different dorsal color patterns. Thus, we designated specimens from two mapped sites in the Municipality of Casas Grandes and from one nearby mapped site in the Municipality of Nuevo Casas Grandes as vividly striped lizards (VSL). Specimens from other mapped sites were designated normally striped lizards (NSL). We observed that the three VSL sites along the base of foothills of the eastern slope of the Sierra Madre Occidental were ecologically different from NSL sites such as El Sueco and Pradera de Janos in central and northwestern Chihuahua, respectively. All VSL specimens possessed wider and more vividly hued primary stripes, whereas the stripes were of normal width and low-contrast color hues in samples NSL-1 and NSL-2. We used samples NSL-1, NSL-2, and VSL for statistical comparisons of means \pm 1 SE for the following characters: snout-vent length (the three arrays had similar maximum SVL measurements and mean differences attributable to the year-class structure of samples); number of granular scales between the paravertebral stripes at midbody (revealing significant differences between some samples); percent of granular scales around midbody situated between the paravertebral stripes at midbody (revealing significant
\end{abstract}

Received 15 February 2018

Accepted 14 May 2018

Distributed June 2018 
differences between all samples); percent of the vertebral field with a vertebral stripe (revealing significant differences between some samples); and clutch size (revealing significant differences between some samples). We concluded that qualitative characters diagnostic of the VSL sample of $A$. uniparens were not accompanied by unique quantitative characters.

Keywords: body size, clutch size, dorsal coloration, dorsal stripes, new variant.

\begin{abstract}
Resumen
Abundancia, variación en el patrón de coloración, ciclo de vida y reproducción en la lagartija triploide partenogenética Aspidoscelis uniparens (Squamata: Teiidae) en Chihuahua, México. Hemos observado a la lagartija triploide partenogenética Aspidoscelis uniparens en sintopía con muchos congéneres, así como en alopatría con ellos mismos, en una área de su distribución que incluye partes de Arizona, Nuevo México y Texas (Estados Unidos), y en Chihuahua y Sonora (México). En julio del año 2000, descubrimos grupos de A. uniparens con un distintivo patrón de coloración dorsal, alopátrica a congéneres en un conjunto de tres sitios en el noroeste de Chihuahua. Estos grupos se distinguen sobre la base de patrones de coloración dorsal sorprendentemente diferentes. Por lo tanto, designamos especímenes de dos sitios ubicados en el municipio de Casas Grandes y de un sitio cercano ubicado en el municipio de Nuevo Casas Grandes como lagartijas vivamente rayadas (VSL). Especímenes de otros sitios mapeados fueron designados como lagartijas normalmente rayadas (NSL). Observamos que los tres sitios VSL a lo largo de la base de las estribaciones de la pendiente oriental de la Sierra Madre Occidental fueron ecológicamente diferentes a los sitios NSL tales como El Sueco y la Pradera de Janos en la parte central y el noroeste de Chihuahua, respectivamente. Todos los especímenes VSL poseyeron rayas primarias más anchas y matices más vividos, mientras que las rayas fueron de anchura normal y un matiz de color de bajo contraste en las muestras NSL-1 y NSL-2. Utilizamos las muestras NSL-1, NSL-2 y VSL para comparaciones estadísticas de las medias \pm 1 SE para los caracteres siguientes; longitud hocicocloaca (los tres grupos tuvieron valores similares de SVL máxima y diferencias promedio atribuibles a la estructura de clases de año de las muestras); número de escamas granulares entre las rayas paravertebrales sobre la parte media del cuerpo, revelando diferencias significativas entre algunas muestras; porcentaje de escamas granulares alrededor de la parte media del cuerpo situados entre las rayas paravertebrales, revelando diferencias significativas entre todas las muestras; porcentaje del campo vertebral con una raya vertebral, revelando diferencias significativas entre algunas muestras; y tamaño de nidada, revelando diferencias significativas entre algunas muestras. Concluimos que caracteres diagnósticos cualitativos de las muestras VSL de A. uniparens no estuvieron acompañadas por caracteres cuantitativos únicos.
\end{abstract}

Palabras clave: coloración dorsal, rayas dorsales, tamaño corporal, tamaño de nidada, variante nueva.

\title{
Resumo
}

Abundância, variação no padrão de coloração, ciclo de vida e reprodução no lagarto partenogenético triploide Aspidoscelis uniparens (Squamata: Teiidae) in Chihuahua, México. Nós observamos o lagarto triploide partenogenético Aspidoscelis uniparens em sintopia, bem como em alopatria, com muitos congêneres, dentro de uma área em partes do Arizona, Novo Mexico e Texas (EUA) e Chihuahua e Sonora (México). Em julho de 2000, descobrimos grupos de A. uniparens com padrões distinto de coloração dorsal, em alopatria com espécies congêneres, em um agrupamento de três localidades do noroeste de Chihuahua. Esses grupos foram distinguidos com base em padrões de coloração dorsal marcadamente diferentes. Desse modo, nós designamos espécimes de duas localidades mapeadas no município de Casas Grandes e de um local mapeado nas proximidades no município de Nuevo Casas Grandes como lagartos com listras vívidas (VSL). Os espécimes de outras localidades mapeadas foram chamados de lagartos com listras normais (NSL). Observamos que as três localidades VSL ao longo da base dos sopés da encosta leste de Sierra Madre 


\begin{abstract}
Ocidental foram ecologicamente diferentes das localidades NSL tais como El Sueco e Pradera de Janos, no centro e no noroeste de Chihuahua, respectivamente. Todos os espécimes VSL exibiram listras primárias mais largas e mais nítidas, enquanto as listras se mostraram de largura normal e coloração de pouco contraste nas amostras NSL-1 e NSL-2. Nós usamos as amostras NSL-1, NSL-2 e VSL para comparações estatísticas de médias \pm 1 SE para os seguintes caracteres: comprimento rostro-cloacal (os três grupos tiveram medidas similares de SVL máximo e diferenças médias atribuíveis à estrutura de classes etárias das amostras); número de escamas granulares entre as listras paravertebrais no meio do corpo (revelando diferenças significativas entre algumas amostras); porcentagem de escamas granulares em torno do meio do corpo situadas entre as faixas paravertebrais no meio do corpo (revelando diferenças significativas entre todas as amostras); porcentagem de campo paravertebral com uma listra vertebral (revelando diferenças significativas entre algumas amostras); e tamanho da desova (revelando diferenças significativas entre algumas amostras). Nós concluímos que os caracteres qualitativos diagnósticos da amostra VSL de A. uniparens não foram acompanhados por caracteres quantitativos exclusivos.
\end{abstract}

Palavras-chave: coloração dorsal, listras dorsais, nova variante, tamanho da desova, tamanho do corpo.

\section{Introduction}

The triploid parthenogenetic species Aspidoscelis uniparens (Wright and Lowe, 1965), Desert Grassland Whiptail, attains high densities in many parts of its distribution area which includes parts of Arizona, New Mexico, and Texas in the United States and Chihuahua and Sonora states in Mexico (Wright and Lowe 1965, Wright 1968, Cuellar 1979, Hulse 1981, Dessauer and Cole 1989, Lemos-Espinal and Smith 2007, Bateman et al. 2010, Lemos-Espinal et al. 2017). As noted by Sullivan et al. (2005), specimens of A. uniparens from Arizona and New Mexico are well represented in several museum collections. However, they also found them to be misidentified in some collections (e.g., Museum of Vertebrate Zoology, University of California Berkeley) as specimens of gonochoristic Aspidoscelis inornatus (Baird, 1859), Little Striped Whiptail. The bases for the misidentifications of these species included similar basic dorsal color patterns (Table 1) and adult body sizes. We have also found A. uniparens, a relatively small hybrid-derived species, to be challenging to identify in northwestern Chihuahua (Figure 1) and extreme southwestern New Mexico, especially juveniles and young adults, both in areas where it was allopatric to congeners (i.e., Appendix I, site 10) and where it was syntopic with either triploid parthenogenetic Aspidoscelis sonorae (Lowe and Wright, 1964), Sonoran Spotted Whiptail (Figure 2, Appendix I, site 4) or gonochoristic A. inornatus (Appendix I, site 3).

In sorting collections of Aspidoscelis obtained by JAL-E from Chihuahua, JMW noted that lizards from two sites in the Municipality of Casas Grandes and one site in the Municipality of Nuevo Casas Grandes (Figures 1-2; Appendix I; sites 8-10), tentatively identified as Aspidoscelis uniparens, had strikingly different dorsal color components compared to specimens from elsewhere in Chihuahua and the United States of America. Thus, we invited H. L. Taylor of Regis University, Denver, Colorado, to examine the specimens; he agreed with our conclusion that those termed herein 'vividly striped' did not represent any other named species from Chihuahua [e.g., Aspidoscelis exsanguis (Lowe, 1956) (Chihuahuan Spotted Whiptail), Aspidoscelis inornatus, or Aspidoscelis sonorae]. We compared characters of color patterns (Table 1) of normally striped lizards (NSL) and vividly striped lizards (VSL) from northwestern Chihuahua (see Lemos-Espinal and 


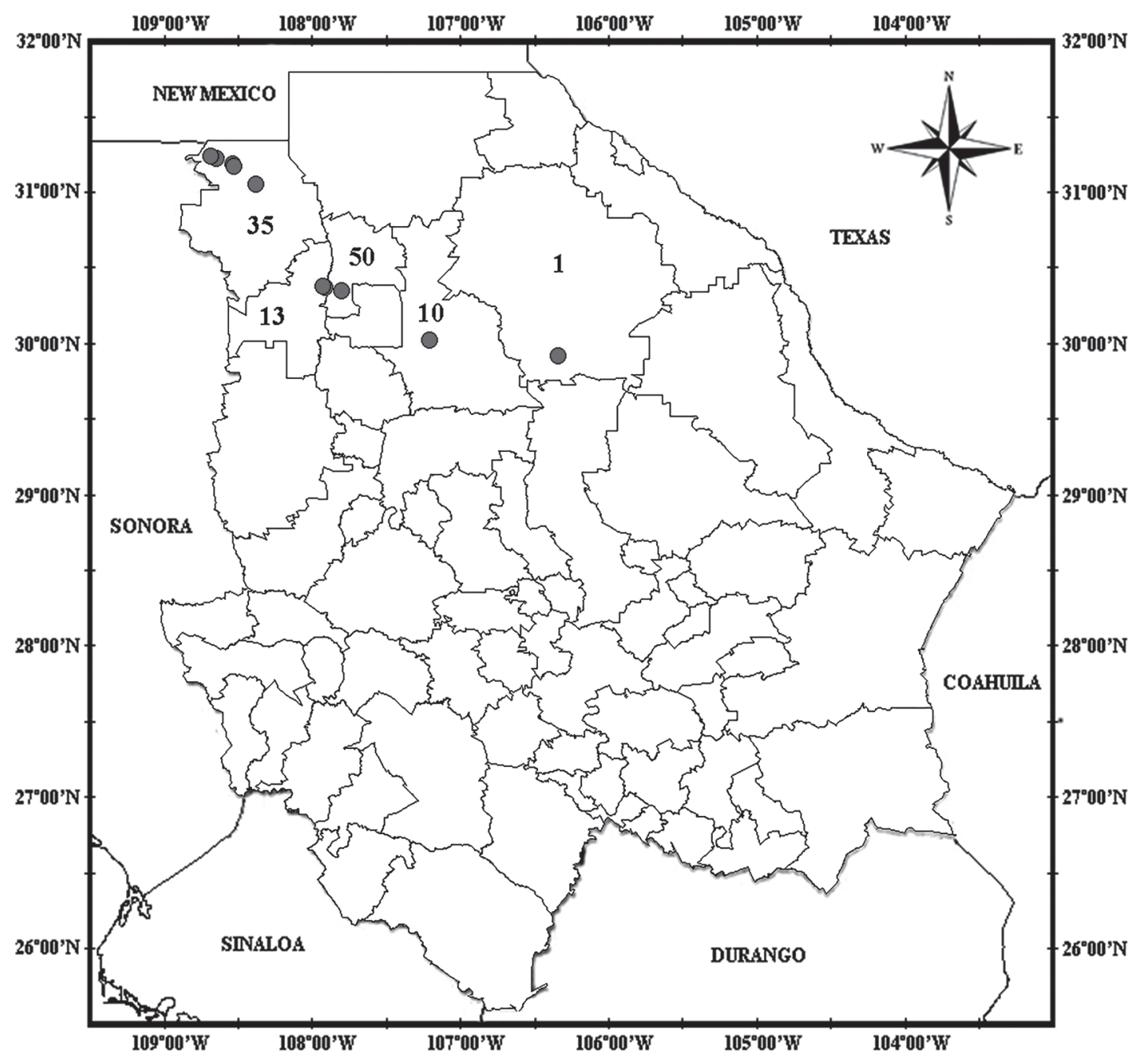

Figure 1. Map showing municipalities of Chihuahua, Mexico; those numbered contain sites of collection for specimens referenced herein. Included were: 1 (Ahumada with site 6); 10 (Buenaventura with site 7); 13 (Casas Grandes with sites 8 and 10); 35 (Janos with sites 1-5); 50 (Nuevo Casas Grandes with site 9).

Smith 2007; map 1, for location of the municipalities cited in our Figure 1 and Appendix I). We also analyzed reproductive characteristics (see Table 1) to determine whether they were correlated with color pattern differences, and we interpreted life histories based on samples recognized as NSL and VSL variants.

\section{Materials and Methods}

\section{Nomenclature}

Reeder et al. (2002) resurrected the generic name Aspidoscelis Fitzinger, 1843 from the synonymy of Cnemidophorus Wagler, 1830 to 

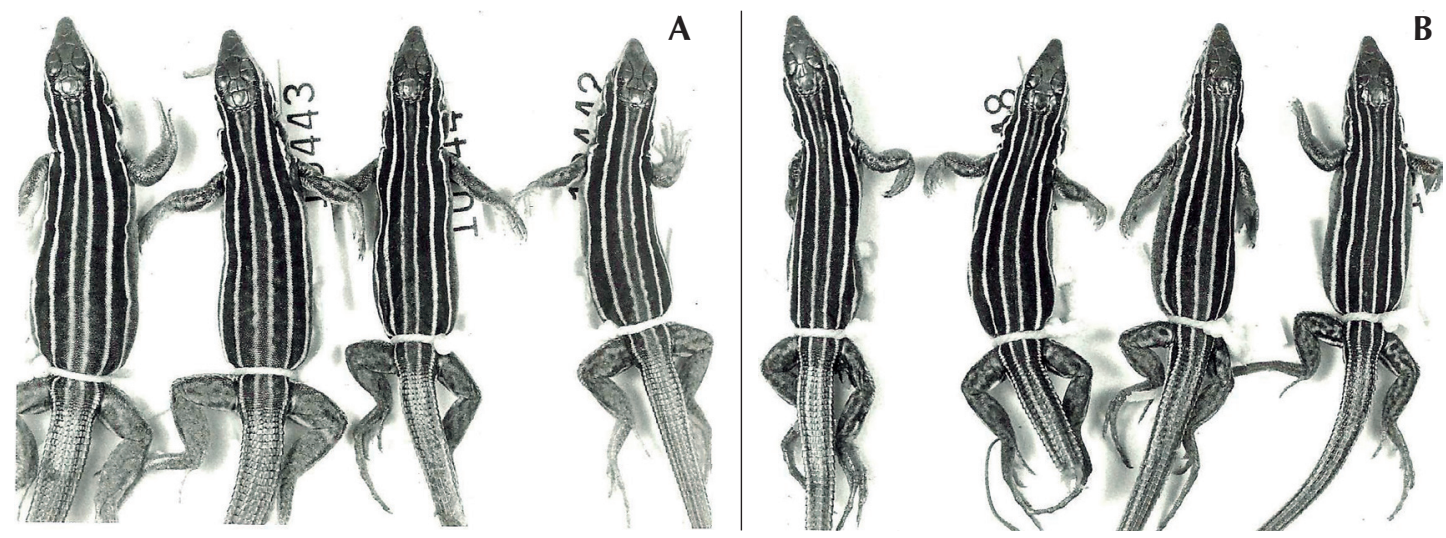

Figure 2. Striking dorsal pattern similarities exhibited by four juveniles (2A: left panel, I. to r.) of Aspidoscelis sonorae (LEUBIPRO 10447 우 of $53 \mathrm{~mm} \mathrm{SVL;} 10443$ 우 of $51 \mathrm{~mm} \mathrm{SVL;} 10444$ 우 of $46 \mathrm{~mm} \mathrm{SVL;} 10442$ 우 of $45 \mathrm{~mm}$ SVL) compared to four juveniles (2B: right panel, I. to r.) of Aspidoscelis uniparens (LEUBIPRO 10445 우 of $45 \mathrm{~mm} \mathrm{SVL} ; 10448$ 우 of $43 \mathrm{~mm} \mathrm{SVL} ; 10455$ 우 of $43 \mathrm{~mm} \mathrm{SVL} ; 10451$ 우 of $42 \mathrm{~mm} \mathrm{SVL}$ ), all collected by JAL-E on 15 September 2003 from Rancho Los Nogales (site 4), Municipality of Janos, Chihuahua, Mexico.

partially correct paraphyly in the latter genus. These authors treated Aspidoscelis as feminine in gender which required emendation of the following specific epithets used herein: inornatus to inornata; tesselatus to tesselata; and neotesselatus to neotesselata. However, based on Steyskal's (1971) explanation of ICZN rules pertaining to the gender of generic names ending in $(u s)$, a paper recently brought to the general attention of herpetologists by Tucker et al. (2016), Aspidoscelis must be treated as masculine in gender. Thus, the aforementioned emendations for the names ending in ( $u s)$ proposed by Reeder et al. (2002) were incorrect. We used common names based on the checklist of the Society for the Study of Amphibians and Reptiles provided by Crother (2017).

\section{Chihuahuan Collection Sites, Samples, and Species Referenced}

Specimens used for textual analyses and construction of Figure 1, Tables $1-3$ and Appendices I-II were collected by JAL-E in partial preparation of the tome on the herpetofauna of Chihuahua (Lemos-Espinal and Smith 2007). We listed the 10 collection sites relevant to this study in northwestern Chihuahua by municipality and the specimens examined by date of collection then by species (Figure 1; Appendix I) to voucher conclusions about syntopic relationships, relative abundance, color pattern variation, and clutch size of Aspidoscelis uniparens. We identified three triploid parthenogenetic species (Aspidoscelis exsanguis, A. sonorae, and $A$. uniparens) and one gonochoristic species (A. inornatus) in collections from among the 10 sites (Figure 1). The latter species, $A$. inornatus, was a member of the originating hybrid parentage of each of the other species. General references to some arrays (i.e., groups) of A. uniparens in the United States of America were based on collections made by JEC.

\section{Qualitative Characters of Dorsal Color Patterns}

We identified specimens of Aspidoscelis from northeastern Chihuahua to species based on 
Table 1. Aspects of color pattern and reproductive structures, analyzed in specimens of triploid parthenogenetic Aspidoscelis uniparens from Chihuahua, Mexico.

\begin{tabular}{|c|c|}
\hline Structure as referenced & Description of structure \\
\hline Paired lateral stripes & Pale-hued primary stripe on each side dorsal to the lateral row of ventral scales \\
\hline Paired dorsolateral stripes & Pale-hued primary stripe on each side dorsal to the lateral stripe \\
\hline Paired paravertebral stripes & Pale-hued primary stripe on each side dorsal to the dorsolateral stripe \\
\hline Single vertebral stripe & Pale-hued secondary stripe between the paravertebral stripes, complete or not \\
\hline Paired lower lateral fields & Gray-brown field on each side ventral to the lateral stripe \\
\hline Paired upper lateral fields & Brown field on each side dorsal to the lateral stripe \\
\hline Paired dorsolateral fields & Brown field on each side dorsal to the dorsolateral stripe \\
\hline Single vertebral field & Brown field between the paravertebral stripes from occiput to base of tail \\
\hline $\mathrm{GAB}=$ Granules around midbody & Granular scales over body from the right lateral row of ventral scales to the left row \\
\hline GPV = Granules between paravertebrals & Granular scales between paravertebral stripes at midbody \\
\hline (GPV/GAB) .100 & Percent of GAB between paravertebral stripes at midbody \\
\hline LVS = Length of vertebral stripe & Vertebral stripe measured to $\mathrm{mm}$ from occipital scales to its posterior termination \\
\hline LVF $=$ Length of vertebral field & Length of vertebral field measured from occipital scales to the base of the tail \\
\hline (LVS/LVF) . 100 & Length of the vertebral stripe divided by the length of vertebral field \\
\hline SVL & Snout to vent length to nearest $\mathrm{mm}$ from tip of snout to cloacal slit \\
\hline Yolked ovarian eggs & Number of follicles $>3 \mathrm{~mm}$ in one or both ovaries; measured to half $\mathrm{mm}$ \\
\hline Oviductal eggs & Number of eggs in the oviducts; length and width measured to half mm \\
\hline Symmetrical clutches & Number of equally distributed eggs in right and left oviduct \\
\hline
\end{tabular}

qualitative dorsal color pattern characters referenced by Burt (1931) and Duellman and Zweifel (1962). Juveniles and adults of Aspidoscelis uniparens, as well as those of parthenogenetic $A$. sonorae and A. exsanguis and gonochoristic A. inornatus, possessed six palecolored longitudinal stripes arranged in three bilateral pairs (see Table 1). As a group, the primary stripes were so-called because they are similarly positioned in all specimens. However, both vividness of cream to cream-white coloration and width of the stripes were geographically variable in $A$. uniparens as evidenced by similarly patterned specimens from sites 8-10 (Figure 3; Appendix I), but differently patterned specimens from other sites inhabited by the species (Figure 3; Appendix I). Present between the variably spaced parasagittal paravertebral stripes in specimens of $A$. uniparens and $A$. inornatus, but not in those of $A$. exsanguis and $A$. sonorae, was a midsagittal secondary stripe (= vertebral) of varying degrees of development in length (i.e., complete or incomplete) and distinctiveness. This secondary stripe was so-called because it was subject to individual, ontogenetic, and/or geographic variation. Sharply bordering both sides of each of the stripes in all specimens of A. uniparens 
were longitudinal mostly dark brown fields (see Table 1 for additional details), all devoid of discrete pale-colored spots which were apparent in adults of $A$. exsanguis and $A$. sonorae.

\section{Quantitative Characters of Dorsal Color Patterns}

We compared two samples of normally striped lizards (samples NSL-1 and NSL-2) and one of vividly striped lizards (samples VSL), all identified to Aspidoscelis uniparens pending genetic assessments, with reference to certain quantitatively derived characters also used in part by Walker et al. (2012) to compare dorsal patterns in Aspidoscelis neotesselatus (Walker,
Cordes, and Taylor, 1997), Colorado Checkered Whiptail, and Aspidoscelis tesselatus (Say, 1823), Common Checkered Whiptail, in southeastern Colorado. These characters [GPV, (GPV/GAB).100, and (LVS/LVF).100] were described in Table 1. We avoided use of qualitative methods of expressing the length of the vertebral stripe in individuals of $A$. uniparens because they were less precisely duplicative (e.g., "usually about to arms only" or "usually complete") as recorded by Cole et al. (2017).

\section{Measurements}

We expressed body size for each specimen of Aspidoscelis uniparens by measuring the snout

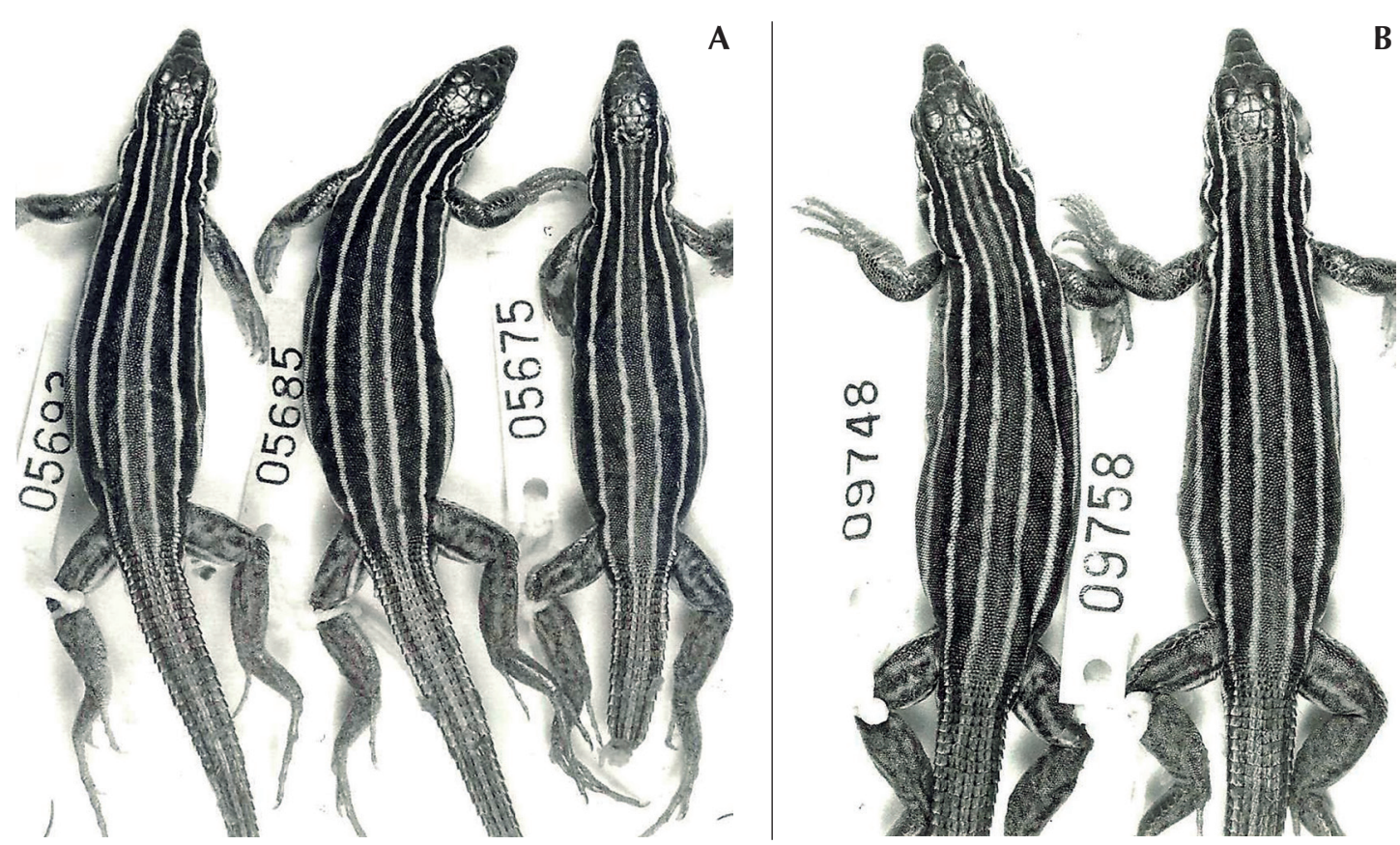

Figure 3. A: Left panel (l. to r.): dorsal patterns of three vividly striped lizards (VSL) identified as Aspidoscelis uniparens (LEUBIPRO 5692 66 mm SVL; 5685 우 68 mm SVL) from km 10 on road from Casas Grandes to Colonia Juárez, Municipality of Nuevo Casas Grandes and (LEUBIPRO; 5675 o 64 mm SVL) from Arroyo los Mimbres, Municipality of Casas Grandes, Chihuahua. B: Right panel (I. to r.) and dorsal patterns of two normally striped lizards (NSL) identified as Aspidoscelis uniparens (LEUBIPRO 9748 우 $69 \mathrm{~mm} \mathrm{SVL;} 9758$ 우 71 mm SVL) from from Caseta Galeana, Llanos Flores Magón, Municipality of Buenaventura, Chihuahua. 
vent length (SVL) to the nearest $\mathrm{mm}$ (Tables 2 and 3). We used these data to determine maximum SVL, year class structure of samples, and estimates of the duration of the life cycle. We analyzed variation in the length of the vertebral stripe (Table 1), measured to the nearest $\mathrm{mm}$, as a percentage of the length of the vertebral field, measured to the nearest $\mathrm{mm}$ (Table 1).

\section{Relative Abundance and Life Cycle}

We found Aspidoscelis exsanguis, A. sonorae, and $A$. uniparens, three parthenogenetic species in the study area (Lemos-Espinal et al. 1997, 2000, 2004, 2017, Smith et al. 1998), to be essentially equally observable and collectable at most sites of occurrence. By comparison, gonochoristic A. inornatus was less easily observable and collectable. We considered the numbers of $A$. uniparens observed and collected at the various sites to be indicative of its relative abundance. Unquestionably, A. uniparens was more abundant at sites either where it was allopatric to all other congeners or was syntopic with only one congener. Based on studies of $A$. uniparens in Arizona (Hulse 1981) and New Mexico (Bateman et al. 2010), we used the year class structure of the samples NSL-1, NSL-2, and VSL to determine the relative duration of the life cycle of the NSL and VSL pattern classes of the species in northeastern Chihuahua.

\section{Reproductive Characteristics}

We compared reproductive characteristics for samples of normally striped (NSL-1 and NSL-2) specimens and for vividly striped (VSL) specimens of Aspidoscelis uniparens which are summarized in Tables 2 and 3. We examined the ovaries for yolked follicles of $>3 \mathrm{~mm}$ in diameter; each one was measured to $0.5 \mathrm{~mm}$ in diameter. We also measured both the length and diameter of oviductal eggs to $0.5 \mathrm{~mm}$. Clutch size for each gravid female was based on either yolked ovarian follicles or oviductal eggs summed from the left and right reproductive organs. We also recorded clutches as either symmetrical or asymmetrical in distribution.

\section{Treatment of Data}

We performed statistical analyses at the University of Arkansas on a PC loaded with institutionally licensed JMP Pro software (Version 13.0.0, SAS Institute, Inc., Cary, North Carolina, Copyright (C) 2016). All data in Tables and selected data in Appendix II include means (to one decimal place) $\pm 1 \mathrm{SE}$, ranges of variation, number of observations, and tests for statistical significance at $p=0.05$.

\section{Results}

Comparisons of Abundance of VSL and NSL Variants

The large numbers of specimens of Aspidoscelis uniparens in the two primary samples of normally patterned A. uniparens (NSL-1 from site $6, N=56$ and NSL-2 from site $7, N=54$ ) were each collected by the same investigator on one day of different years. Additional evidence of the abundance of the NSL variant on sandy substrates consisted of the number of A. uniparens observed, but not collected during the visit to each site. In contrast, the VSL variant (pooled sample, $N=$ 29) was less abundant on rocky substrates based on collecting results at sites $8,(N=14), 9(N=$ $9)$, and $10(N=6)$, with few additional $A$. uniparens observed during the visits. $A$. uniparens was the only whiptail lizard species observed at sites 7 and 10 and it was the numerically dominant species with a few $A$. inornatus at site 6. Similar high levels of abundance as observed at sites 6 and 7 were also found at sites for the species in Arizona and New Mexico by other investigators (e.g., Wright 1968, Cuellar 1979, Sullivan et al. 2005, Cordes unpubl. data). 


\section{Comparisons of Body Size}

We derived SVL data for specimens of Aspidoscelis uniparens pooled from the municipalities of Casas Grandes, and Nuevo Casas Grandes, Chihuahua (sample VSL from sites 8-10; Figure 1; Appendix I) from 03-04 July 2000. All of these specimens displayed wide and highly contrasted (= vivid) cream to cream-white primary stripes sharply bordered by dark brown fields. The contents of pooled sample VSL, 29 adults with a SVL mean of $64.2 \pm 0.93$ and range of $59-75 \mathrm{~mm}$, based on $5 \mathrm{~mm}$ groupings where applicable, were included in Table 2. We derived SVL data for specimens of A. uniparens from the municipalities of Ahumada (NSL-1; site 6, Figure 1; Table 2) from 07 July 2000 and Buenaventura (NSL-2; site 7, Figure 1; Table 2) from 21 July 2002; all specimens displayed primary stripes of normal width and subdued cream-hued coloration. The contents of sample NSL-1, 56 juveniles and adults with a SVL mean of $58.2 \pm 0.67$ and range of 49-76 $\mathrm{mm}$, based on $5 \mathrm{~mm}$ groupings where applicable, were included in Table 2. The contents of sample NSL-2, 54 adults with a SVL mean of $65.2 \pm$
0.68 and range of $55-76 \mathrm{~mm}$, based on $5 \mathrm{~mm}$ SVL groupings where applicable, are also included in Table 2. Comparison of means for SVL for each of the three samples revealed that VSL and NSL-1, both collected in July 2000, were significantly different $\left(F_{2,136}=30.2819, p\right.$ $\leq$ 0001), whereas SVL means for VSL and NSL-1, collected in July of different years, were not significantly different.

\section{Striping Patterns}

We quantitatively analyzed three characters pertaining to the dorsal striping pattern in Aspidoscelis uniparens as revealed by two NSL and one VSL samples. We discovered that most specimens in sample NSL-2 were seven-striped. In these individuals a complete midsagittal secondary stripe (= vertebral) varying from indistinct (i.e., barely visible) to moderately distinct was present in 39 of $54(72.2 \%)$ lizards, with a mean SVL of $64.6 \pm 1.26$ and range of 55-76 mm. An incomplete vertebral stripe varying from indistinct to moderately distinct was present in only 15 of $54(27.8 \%)$ specimens in sample NSL-2 with a mean SVL of $66.9 \pm$

Table 2. Sample content, based on $5 \mathrm{~mm}$ SVL groupings where applicable, of three samples of Aspidoscelis uniparens collected from different sites by JAL-E from Chihuahua, Mexico. Numbers for each group includes SVL group measured to nearest $\mathrm{mm}$ (number and \% of total gravid females; range and group \% of lizards void of clutches).

\begin{tabular}{|c|c|c|}
\hline $\begin{array}{l}\text { Site 6; Sample NSL-1 }(N=56) \\
\text { SVL Group (Gravid, \%; Total, \%) }\end{array}$ & $\begin{array}{l}\text { Site 7; Sample NSL-2 }(N=54) \\
\text { SVL Group (Gravid, \%; Total, \%) }\end{array}$ & $\begin{array}{l}\text { Sites 8-10; Sample VSL }(N=29) \\
\text { SVL Group (Gravid, \%; Total, \%) }\end{array}$ \\
\hline $49 \mathrm{~mm}(0,0 \% ; 2,3.6 \%)$ & - & - \\
\hline $50-54$ mm $(4,16.7 \% ; 19,33.9 \%)$ & - & - \\
\hline $55-59$ mm (7, 29.2\%; 11, 19.6\%) & $55-56 \mathrm{~mm}(0,0 \% ; 2,3.7 \%)$ & $59 \mathrm{~mm}(2,7.4 \% ; 2,6.9 \%)$ \\
\hline $60-64$ mm (5, 20.8\%; 13, 23.2\%) & $60-64 \mathrm{~mm}(15,45.5 \% ; 23,42.6 \%$ & 60-64 mm (16, 59.3\%; 18, 62.1\%) \\
\hline $65-69 \mathrm{~mm}(6,25.0 \% ; 9,16.1 \%)$ & 65-69 mm (12, 36.6\%; 21, 38.9\%) & 65-69 mm (5, 18.5\%; 5, 17.2\%) \\
\hline $70-74 \mathrm{~mm}(1,4.2 \% ; 1,1.8 \%)$ & $70-73 \mathrm{~mm}(5,15.2 \% ; 7,13.0 \%)$ & $70-74 \mathrm{~mm}(3,11.1 \% ; 3,10.3 \%)$ \\
\hline $76 \mathrm{~mm}(1,4.2 \% ; 1,1.8 \%)$ & $76 \mathrm{~mm}(1,3.0 \% ; 1,1.9 \%)$ & $75 \mathrm{~mm}(1,3.7 \% ; 1,3.4 \%)$ \\
\hline Totals $(24,100 \% ; 56,100 \%)$ & Totals $(33,100 \% ; 54,100 \%)$ & Totals $(27,100 \% ; 29,100 \%)$ \\
\hline
\end{tabular}


1.06 and range of $60-73 \mathrm{~mm}$. We concluded that presence or absence of a complete vertebral stripe was not SVL dependent owing to overlap in individual variation in the subsamples. The mean and range for SVL for all of sample NSL-2 were included in Table 3.

The length of the vertebral stripe as a percentage of the length of the vertebral field (LVS/LVF). 100 for 15 of 54 (27.8\%) specimens of Aspidoscelis uniparens in sample NSL-2 was $36.4 \pm 1.48(21.2-49.0 \%)$; see Table 3 for the mean (LVS/LVF).100, GPV, and (GPV/ GAB).100 for the pooled NSL-2 sample (= seven and six plus striped specimens).

Sample VSL comprised three subsamples (Appendix I; sites 8-10) for a pooled total of 29 specimens of A. uniparens (based on current taxonomic treatment) from the municipalities of Casas Grandes and Nuevo Casas Grandes from 03-04 July 2000. All specimens had a distinctive dorsal pattern pertaining to the vividness of color and width of the six primary stripes (Table 1). The subsamples were separately referenced for all characters in Tables 2 and 3; only data for the pooled VSL sample are presented here. Percentage of the vertebral field with a partial vertebral stripe (LVS/LVF).100 in 29 specimens in sample VSL was a mean of $19.3 \pm 4.44$ and range of 14.2-34.6, which was significantly lower $(p=0.05)$ than for the specimens in sample NSL-2 with complete and incomplete vertebral stripes (Table 3). Also, specimens of NSL-1 $(N=55)$ possessed a longer partial vertebral stripe than did VSL, mean of $26.7 \pm$

Table 3. Comparisons of aspects of dorsal color pattern and clutch size in two arrays of triploid parthenogenetic Aspidoscelis uniparens from northern Chihuahua, Mexico. Abbreviations: NSL = normally striped lizards; $\mathrm{VSL}=$ vividly striped lizards; DCPV = dorsal color pattern variant; SVL = snout-vent length; GPV = count granules in a line between the paravertebral stripes; $(\mathrm{GPV} / \mathrm{GAB}) .100=$ percentage of granules round midbody (GAB) located between the paravertebral stripes; (LVS/LVF).100 = percentage of the vertebral field occupied by the vertebral stripe; and CS = mean clutch size. Sample means \pm SE with different superscripted letters are significantly different $(p=0.05)$.

\begin{tabular}{lccccc}
\hline DCPV Designation & SVL & GPV & GPV/GAB $\%$ & LVS/LVF \% & CS \\
\hline NSL-1, SITE 6 & $58.2 \pm 0.68^{\mathrm{B}}$ & $5.1 \pm 0.10^{\mathrm{B}}$ & $6.9 \pm 0.14^{\mathrm{C}}$ & $26.7 \pm 2.56^{\mathrm{B}}$ & $2.3 \pm 0.13^{\mathrm{B}}$ \\
POOLED & $49-76(56)$ & $4-7(55)$ & $5.0-9.3(56)$ & $15.0-58.8(55)$ & $2-5(24)$ \\
NSL-2, SITE 7 & $65.2 \pm 0.49^{\mathrm{A}}$ & $6.4 \pm 0.10^{\mathrm{A}}$ & $9.1 \pm 0.14^{\mathrm{A}}$ & $82.3 \pm 2.58^{\mathrm{A}}$ & $2.4 \pm 0.11^{\mathrm{B}}$ \\
POOLED & $55-76(54)$ & $4-8(54)$ & $5.6-11.1(54)$ & $21.2-100(54)$ & $2-4(33)$ \\
& & & & & \\
VSL, SITES 8-10 & $64.3 \pm 0.93^{\mathrm{A}}$ & $5.2 \pm 0.11^{\mathrm{B}}$ & $7.6 \pm 0.20^{\mathrm{B}}$ & $19.3 \pm 3.53^{\mathrm{B}}$ & $2.9 \pm 0.12^{\mathrm{A}}$ \\
POOLED & $59-75(29)$ & $4-7(29)$ & $5.7-10.2(29)$ & $14.2-34.6(29)$ & $2-4(27)$ \\
NSL-2, SITE 7 & $64.6 \pm 0.60^{\mathrm{A}}$ & $6.5 \pm 0.13^{\mathrm{A}}$ & $9.2 \pm 0.17^{\mathrm{A}}$ & $100^{\mathrm{A}}$ & $2.4 \pm 0.11^{\mathrm{A}}$ \\
7-STRIPED SUBSAMPLE & $55-76(39)$ & $4-8(39)$ & $5.6-11.1(39)$ & $100(39)$ & $2-4(24)$ \\
NSL-2, SITE 7 & $66.9 \pm 0.98^{\mathrm{A}}$ & $6.2 \pm 0.11^{\mathrm{A}}$ & $8.7 \pm 0.14^{\mathrm{A}}$ & $36.4 \pm 1.4^{\mathrm{B}}$ & $2.3 \pm 0.17^{\mathrm{A}}$ \\
6+ STRIPED SUBSAMPLE & $60-73(15)$ & $6-7(15)$ & $7.9-9.9(15)$ & $21.2-49.0(15)$ & $2-3(9)$ \\
VSL-1, SITE 8 & $63.2 \pm 0.83^{\mathrm{B}}$ & $5.9 \pm 0.18^{\mathrm{A}}$ & $8.6 \pm 0.23^{\mathrm{A}}$ & $21.1 \pm 1.08^{\mathrm{A}}$ & $2.9 \pm 0.16^{\mathrm{AB}}$ \\
SUBSAMPLE & $59-70(14)$ & $5-7(14)$ & $7.2-10.2(14)$ & $14.2-34.6(14)$ & $2-4(13)$ \\
VSL-2, SITE 9 & $67.9 \pm 1.03^{\mathrm{A}}$ & $4.7 \pm 0.22^{\mathrm{B}}$ & $6.7 \pm 0.28^{\mathrm{B}}$ & $17.6 \pm 1.34^{\mathrm{A}}$ & $3.2 \pm 0.1^{\mathrm{A}}$ \\
SUBSAMPLE & $61-75(9)$ & $4-6(9)$ & $5.7-8.2(9)$ & $15.0-21.0(9)$ & $2-4(9)$ \\
VSL-3, SITE 10 & $60.8 \pm 1.27^{\mathrm{B}}$ & $4.5 \pm 0.27^{\mathrm{B}}$ & $6.4 \pm 0.35^{\mathrm{B}}$ & $17.8 \pm 1.65^{\mathrm{A}}$ & $2.2 \pm 0.29^{\mathrm{B}}$ \\
SUBSAMPLE & $59-62(6)$ & $4-5(6)$ & $5.7-7.3(6)$ & $14.2-20.8(6)$ & $2-3(5)$ \\
\hline
\end{tabular}


0.96 and range of $15.0-58.5 \%$. Comparison of means for incomplete vertebral stripes in samples VSL, NSL-1, and the six-plus striped subsample of NSL-2 (Table 3) revealed that all three were significantly different $\left(F_{2,96}=29.0776, p \leq 0001\right)$.

Analyses of the number of granular scales between the paravertebral stripes (GPV) revealed significant mean differences between NSL-2 (6.4 $\pm 0.11)$ and each of NSL- $1(5.1 \pm 0.11)$ and VSL $(5.2 \pm 0.15)$, but not between NSL-1 and VSL. The higher value for NSL-2 was correlated with the presence of a complete vertebral stripe in 39 of $54(72.2 \%)$ specimens, whereas none of the specimens in either samples NSL-1 or VSL were seven-striped, Analyses of the percentage of the granular scales around midbody situated between the paravertebral stripes (GPV/GAB).100 revealed significant differences between all combinations of samples NSL-1 $(6.9 \pm 0.15)$, NSL-2 $(9.1 \pm 0.15)$, and VSL $(7.6 \pm 0.21)$.

\section{Reproductive Characteristics}

We asked if the striking qualitative distinction between the dorsal patterns of VSL compared with NSL-1 and NSL-2 samples of Aspidoscelis uniparens was correlated with differences in reproductive characteristics? We found that 27 of $29(93.1 \%)$ VSL specimens of in three pooled VSL subsamples were gravid from the 03-04 July 2000 collection, whereas only 24 of 56 $(42.9 \%)$ of NSL-1 specimens from Municipality of Ahumada were gravid in the 07 July 2000 sample of the species. Many specimens in the NSL-1 sample were of reproductive SVL (> 52 $\mathrm{mm} \mathrm{SVL}, 22$ of $56=39.3 \%$ ) indicating that they had recently either oviposited clutches or had yet to develop clutches (some of 53-55 mm SVL). Only 33 of $54(61.1 \%)$ NSL-2 specimens from Municipality of Buenaventura of were gravid in the late July 2002 sample of the species. Many specimens in the NSL-2 sample were also of reproductive SVL ( $>59 \mathrm{~mm} \mathrm{SVL}, 19$ of $21=$ $90.5 \%$ ) indicating that they had recently oviposited clutches. Comparison of reproductive characteristic for the samples revealed the following: minimum and maximum sizes of gravid females, 53-76 mm SVL for NSL-1, 59$75 \mathrm{~mm}$ SVL for VSL and 60-76 mm SVL for NSL-2; mean SVL for gravid females, $61.4 \pm$ $0.92 \mathrm{~mm}, N=24$ for NSL-1, $65.8 \pm 0.78 \mathrm{~mm}, N$ $=33$ for NSL-2, $64.3 \pm 0.87 \mathrm{~mm}, N=27$; and clutch size, $2.3 \pm 0.13,2-5, N=24$ for NSL-1, $2.4 \pm 0.10,2-4, N=33$ for NSL-2 and $2.9 \pm$ $0.12,2-4, N=27$ for VSL (highest mean significantly different from two lower means; $\left.F_{2,81}=6.9401, \quad p=0.0015\right)$. Reproductive characteristics for NSL-2 subsamples and VSL subsamples, are summarized in Table 3.

\section{Discussion}

Although strikingly different in the vividness of dorsal color patterns components, at a level of distinctiveness that would also visually distinguish Aspidoscelis uniparens from both parthenogenetic $A$. sonorae and gonochoristic $A$. inornatus, we found no quantitative character of color pattern to be diagnostic of VSL versus NSL samples. Neither are there quantitative diagnostic differences between the similarly patterned juveniles of $A$. uniparens and $A$. sonorae (Figure 2). We could not attribute the qualitative distinctiveness of VSL subsamples of A. uniparens from sites 8-10 to recent ecdysis, ontogenetic variation, stage of the reproductive cycle, habitat-blending seasonal variation or factors other than inferred genetic differences. However, we contribute additional evidence of phenotypic variation in a clonally reproducing all-female triploid species which extends that reported by Wright (1968) and Cole et al. (2017).

Only 12 of $139(8.6 \%)$ lizards pooled from two NSL and one VSL samples of A. uniparens, exceeded $69 \mathrm{~mm} \mathrm{SVL}$. This is consistent with an abbreviated life cycle for both NSL and VSL variants of A. uniparens in northern Chihuahua, likely spanning parts of 2-3 activity cycles (one $\mathrm{AC}=$ from late April through early October; hatching from late July well into August of the first year, growth to sexual maturity in the second $\mathrm{AC}$, and survival of a few lizards into the third 
AC). Hulse (1981) considered his data for $A$. uniparens from Cochise County, Arizona, to indicate an annual life cycle (i.e., parts of two AC; hatchlings from mid-July possibly into September in the first AC, their rapid growth into autumn, retirement for the winter, and maturity by late May of the second AC), which would only require a few lizards to survive into a third activity cycle to be consistent with our interpretation. We consider it likely that lizards of greater than $\sim 69 \mathrm{~mm} \mathrm{SVL}(8.6 \%)$ in our samples were in their third activity cycle. Bateman et al. (2010), from a mark-recapture study of A. uniparens in a riparian forest extending from Albuquerque to Bosque del Apache National Wildlife Refuge in New Mexico, found that of 402 marked hatchlings, only four $(9.9 \%)$, two $(4.9 \%)$, and one $(2.5 \%)$ were recaptured in each of the next three $\mathrm{AC}$, respectively. These data confirmed that $A$. uniparens is not an entirely annual species $=$ two $\mathrm{AC}$, which is as we concluded for Chihuahua arrays of the species.

Hulse (1981) reported the following reproductive characteristics for A. uniparens from Cochise County, Arizona: clutch size, 2.77 $\pm 0.06,1-4, N=105$ and SVL, $65.5 \pm 3.9,58$ $77, N=145$. Our numbers for one VSL and two NSL samples of A. uniparens from Chihuahua were: clutch size, $2.3 \pm 0.13,2-5, N=24$ for NSL-1 and $2.4 \pm 0.11,2-4, N=33$ for NSL-2 versus $2.9 \pm 0.12,2-4, N=27$ for VSL.

The most significant finding in this study is discovery of a variant of A. uniparens (i.e., pattern class sensu Zweifel 1965) which inhabits an unusual trio of sites, one in the absence of gonochoristic congeners (sensu Wright and Lowe 1968). Sites 8-10 for A. uniparens are located near large human establishments, especially sites 9 and 10 . Although none of the actual habitats described are highly disturbed, they are surrounded by areas subject to anthropogenic degradation. Uniquely, sites 9 and 10 have rocky substrates utilized by the VSL variant of A. uniparens, which was surprising given the usual desert-grassland sandy / gravelly sites inhabited by the species. Site 8 was also unusual for the species because VSL individuals of A. uniparens were collected in a stream bed periodically inundated by flash flooding. The location of these three sites is along the base or foothills of the eastern slope of the Sierra Madre Occidental and are quite different than those from central Chihuahua (e.g., at El Sueco), or from northwestern Chihuahua at Pradera de Janos. The sites near Casas Grandes (= Paquimé), associated with rocky hills, are surrounded by scrublands or grasslands intermittently intensively utilized by humans since ca. 1130. The Sierra Madre Occidental west of these sites is dominated by pine-oak forest. The Sierra de San Luis in northwestern Chihuahua is dominated by juniper-oak woodlands. Neither of these upland associations are inhabited by A. uniparens. The genetic relationships among the NSL and VSL arrays in Chihuahua presently allocated to $A$. uniparens, and their relationships to arrays allocated to the species in Sonora, Arizona, New Mexico, and Texas remain problematic.

\section{Acknowledgments}

Funding to JAL-E was provided by Dirección General del Personal Académico-Programa de Apoyo a Proyectos de Investigación e Innovación Tecnológica (DGAPA-PAPIT), through the project IN215418. Specimens of Aspidoscelis referenced herein were collected in Chihuahua by JAL-E in 2000 and 2002 and imported to the University of Colorado Museum of Natural History for study by HMS under authority of permits provided by the government of Mexico. The specimens were then shipped to the University of Arkansas for further analyses by JMW. They were subsequently deposited in the collections of the University of Colorado Museum of Natural History in Boulder, Colorado, and Laboratorio de Ecología, Unidad de Biotecnología y Prototipos, Facultad de Estudios Superiores Iztacala, UNAM, Estado de México, México. We thank H. L. Taylor, Regis University, for providing an opinion on the identity of specimens in the VSL sample of putative Aspidoscelis uniparens. 


\section{References}

Bateman, H. L., H. L. Snell, A. Chung-MacCoubrey, and D. M. Finch. 2010. Growth, activity, and survivorship from three sympatric parthenogenetic whiptails (Family Teiidae). Journal of Herpetology 44: 301-306.

Burt, C. E. 1931. A study of the teiid lizards of the genus Cnemidophorus with special reference to their phylogenetic relationships. Bulletin United States National Museum 154: 1-286.

Cole, C. J., H. L. Taylor, W. B. Neaves, D. P. Baumann, A. Newton, R. Schnittker, and P. Baumann. 2017. The second known tetraploid species of parthenogenetic tetrapod (Reptilia: Squamata: Teiidae): description, reproduction, comparisons with ancestral taxa, and origins of multiple clones. Bulletin of the Museum of Comparative Zoology 161: 285-321.

Crother, B. I. (ed.). 2017. Scientific and standard English names of Amphibians and Reptiles of North America North of Mexico, with comments regarding confidence in our understanding. $8^{\text {th }}$ Edition. SSAR Herpetological Circular 43: 1-102.

Cuellar, O. 1979. On the ecology of coexistence in parthenogenetic and bisexual lizards of the genus Cnemidophorus. American Zoologist 19: 773-786.

Dessauer, H. C. and C. J. Cole. 1989. Diversity between and within nominal forms of unisexual teiid lizards. Pp. 4971 in R. M. Dawley and J. P. Bogart (eds.), Evolution and Ecology of Unisexual Vertebrates. New York State Museum Bulletin 466.

Duellman, W. E. and R. G. Zweifel. 1962. A synopsis of the lizards of the sexlineatus group (genus Cnemidophorus). Bulletin of the American Museum of National History 123: $155-210$.

Hulse, A. C. 1981. Ecology and reproduction of the parthenogenetic lizard Cnemidophorus uniparens (Teiidae). Annals of the Carnegie Museum 50: 353369.

Lemos-Espinal, J. A. and H. M. Smith. 2007. Anfibios y Reptiles del Estado de Chihuahua, México. México, D. F. Universidad Nacional Autonoma de Mexico, CONABIO. 613 pp.

Lemos-Espinal, J. A., D. Chiszar, and H. M. Smith. 2004. Selected records of 2003 lizards from Chihuahua and Sonora, Mexico. Bulletin of the Chicago Herpetological Society 39: 164-168.

Lemos-Espinal, J. A., H. M. Smith, and D. Chiszar. 2000. New distributional and variational data on some species of lizards from Chihuahua, Mexico. Bulletin of the Chicago Herpetological Society 35: 181-187.

Lemos-Espinal, J. A., J. M. Walker, and H. M. Smith. 2017. Natural History Notes. Aspidoscelis uniparens (Desert Grassland Whiptail). Reproduction. Herpetological Review 48: 639.
Lemos-Espinal, J. A., H. M. Smith, R. E. Ballinger, G. R. Smith, and D. Chiszar. 1997. A herpetological collection from northern Chihuahua Mexico. Bulletin of the Chicago Herpetological Society 32: 198-201.

Reeder, T., H. C. Dessauer, and C. J. Cole. 2002. Phylogenetic relationships of whiptail lizards of the genus Cnemidophorus (Squamata: Teiidae): a test of monophyly, reevaluation of karyotypic evolution, and review of hybrid origins. American Museum Novitates 3365: 1-61.

Smith, H. M., D. Chiszar, C. Henke, J. A. Lemos-Espinal, and F. Van Breukelen. 1998. Field observations on the behavior of Chihuahuan spotted whiptail lizards (Cnemidophorus exsanguis). Bulletin of the Maryland Herpetological Society 34: 34-37.

Steyskal, G. C. 1971. On the grammar of names formed with -scelus, -sceles, -scelis, etc. Proceedings of the Biological Society of Washington 84: 7-11.

Sullivan, B. K., P. S. Hamilton, and M. A. Kwiatkowski. 2005. The Arizona striped whiptail: past and present. Pp. 145-148 in G. J. Gottfried, B. S. Gebow, L. G. Eskew, and C. B. Edminster (eds.), Connecting Mountain Islands and Desert Seas: Biodiversity and Management of the Madrean Archipelgo II. Fort Collins. Proceedings RMRS-P-36 United States Department of Agriculture, Forest Service Rocky Mountain Research Station.

Tucker, D. B., G. R. Colli, L. G. Giugliano, S. B. Hedges, C. R. Hendry, E. M. Lemmon, A. R. Lemmon, J. W. Sites Jr., and R. A. Pyron. 2016. Methodological congruence in phylogenomic analyses with morphological support for teiid lizards (Sauria: Teiidae). Molecular Phylogenetics and Evolution 103: 75-84.

Walker, J. M., H. L. Taylor, G. J. Manning, J. E. Cordes, C. E. Montgomery, L. J. Livo, S. Keefer, and C. Loeffler. 2012. Michelle's lizard: identity, relationships, and ecological status of an array of parthenogenetic lizards (genus Aspidoscelis: Squamata: Teiidae) in Colorado, USA. Herpetological Conservation and Biology 7: 227 248.

Wright, J. W. 1968. Variation in three sympatric sibling species of whiptail lizards, genus Cnemidophorus. Journal of Herpetology 1: 1-20.

Wright, J. W. and C. H. Lowe. 1965. The rediscovery of Cnemidophorus arizonae Van Denburgh. Journal of the Arizona Academy of Science 3: 164-168.

Wright, J. W. and C. H. Lowe. 1968. Weeds, polyploids, parthenogenesis, and the geographical and ecological distribution of all-female species of Cnemidophorus. Copeia 1968: 128-138.

Zweifel, R. G. 1965. Variation in and distribution of the unisexual lizard, Cnemidophorus tesselatus. American Museum Novitates 2235: 1-49.

Editor: Jaime Bertoluci 
Appendix I. Specimens of triploid parthenogenetic Aspidoscelis uniparens and congeners (A. exsanguis, A. sonorae, and/or A. inornatus) examined from Chihuahua, Mexico, all collected by JAL-E. They were initially tagged with numbers of Laboratorio de Ecología, Unidad de Biotecnología y Prototipos = LEUBIPRO; however, some specimens were transferred to and reassigned numbers in the University of Colorado Museum of Natural History =UCM.

1. Mexico: Chihuahua: Municipality of Janos: Entrada al Cañón de la Madera, Sierra de San Luis, $31.214833^{\circ} \mathrm{N}, 108.69775^{\circ}$ W, WGS 84, 1612 m. a.s.1.

25 July 2002

Aspidoscelis uniparens (LEUBIPRO 9888, 9896, 9898, 9905, 9907, 9909, 9917, 9919, 9924, $N=9$ ).

Aspidoscelis exsanguis (LEUBIPRO 9916, $N=1$ ).

Aspidoscelis sonorae (LEUBIPRO 9890-9895, 9897, 9899-9904, 9906, 9908, 9910-9915, 9918, 9920-9923, 9925, N $=27)$.

26 July 2002

Aspidoscelis sonorae (LEUBIPRO 9990-9992, $N=3$ ).

This, a gravelly-sandy riparian corridor at the mouth of a stream from the mountains (Sierra de San Luis) to a meadow (Pradera de Janos), was a wild, remote, and relatively undisturbed site in extreme northwestern Chihuahua. It was accessible only by $4 \times 4$ vehicle and was grazed by a few cattle, though it was not actual pastureland. The stream bed was surrounded by willow trees. About $50 \mathrm{~m}$ westward was a fence that barred the entrance, though a dirt road extended about $150 \mathrm{~m}$ into the canyon. The entrance to the canyon, flanked by very eroded low mountains, had river stones embedded in soil. The dominant vegetation of the mountains included bush-like junipers intermixed with oaks. Though not dense, the oaks provided ample shade. Three triploid parthenogenetic species of Aspidoscelis were present in the absence of gonochoristic species (see Wright and Lowe 1968), A. sonorae being most abundant. Also observed were the lizards Holbrookia approximans, Phrynosoma ornatissimum, Urosaurus ornatus, and Sceloporus clarkii, and the snake Crotalus molossus.

2. Mexico: Chihuahua: Municipality of Janos: Parte media del Cañón de la Madera, Sierra de San Luis, $31.225306^{\circ}$ N, $108.734861^{\circ} \mathrm{W}$, WGS 84,1638 m. a.s.1.

25 July 2002

Aspidoscelis exsanguis (LEUBIPRO 10035, 1036, 10039, 10040, $N=4)$.

Aspidoscelis sonorae (LEUBIPRO 10033, 10034, 10037, 10038, 10041, N = 5).

15 September 2002

Aspidoscelis exsanguis (LEUBIPRO 10396-10398, $N=3$ ).

Aspidoscelis sonorae (LEUBIPRO 10395, $N=1$ ).

The substrate was compacted grayish soil; however, many reddish rocks of ca. $50 \mathrm{~cm}$ in diameter had fallen from the mountains to the sides of the canyon carved by what remains a pristine stream. Oaks of 3-4 m tall were dominant. The substrate in this pristine area, one of the most carefully conserved in Chihuahua, was covered by oak leaf litter. Westward, the woodland became much denser and, although still dominated by oaks, there were also tall Alamos and willow trees. Trees had fallen on the path preventing an unimpeded walk through the canyon, and in the stream. Two species of triploid Aspidoscelis lizards were abundant on the sides of the stream and were quite unwary (A. uniparens was not observed in this part of the canyon). This remote area, mostly free of human activity, connects the Municipality of Janos, Chihuahua, to the municipality of Agua Prieta, Sonora. Other herpetozoans observed here included snakes (Crotalus lepidus, Crotalus willardi obscurus, Lampropeltis knoblochi, Masticophis flagellum, and Thamnophis cyrtopsis), recently hatched turtles (Kinosternon sonoriense), frogs (Anaxyrus punctatus), and lizards (Urosaurus ornatus, Holbrookia approximans, Sceloporus clarkii, and Sceloporus virgatus).

3. Mexico: Chihuahua: Municipality of Janos: Entrada a Pradera de Janos, km 28 carretera Janos Agua Prieta, $31.044222^{\circ}$ N, $104.43075^{\circ} \mathrm{W}$, WGS 84,1392 m. a.s.1.

27 July 2002

Aspidoscelis uniparens (LEUBIPRO 10050, 10052, $N=2$ ).

Aspidoscelis inornatus (LEUBIPRO 10049, $N=1$ ).

28 July 2002

Aspidoscelis uniparens (LEUBIPRO 10096-10103, 10105, $N=9$ ).

Aspidoscelis inornatus (LEUBIPRO 10095, 10104, 10106-10108, $N=5$ ).

This was a large severely degraded grassland with numerous mesquite trees. The substrate here was mostly sandy, but with some scattered gravelly patches. The area was subject to flooding, and cattle from area ranches were ubiquitous. Two species of Aspidoscelis lizards were mostly collected in the limited number of patches of habitat with mesquite trees in eroded terrain 


\section{Appendix I. Continued}

with large a number of prairie dogs. Walking at the site was difficult because each step resulted in a collapsed burrow. This extensive prairie is surrounded by the Sierra de San Luis to the west, and by small isolated sierras to the south.

4. Mexico: Chihuahua: Municipality of Janos: Rancho los Nogales, $31.175722^{\circ} \mathrm{N}, 108.586027^{\circ} \mathrm{W}$, WGS $84,1461 \mathrm{~m}$ a.s.1.

18 September 2002

Aspidoscelis uniparens (LEUBIPRO 10445, 10448, 10451, 10454-10458, N = 8).

Aspidoscelis sonorae (LEUBIPRO 10442-10444, 10446, 10447-10450, 10452, 10453, 10459, N = 10).

20 September 2002

Aspidoscelis uniparens (LEUBIPRO 10468-10472, 10475-10476, N = 7).

Aspidoscelis sonorae (LEUBIPRO 10474, $N=1$ ).

Rancho los Nogales, was located on the western end of Sierra de En Medio, and was within the Reserva de la Biosfera Janos. It encompassed mostly sandy gravelly terrain grazed by many cattle herded by five blue heelers (Australian cattle dogs). It was surrounded by a mesquite (Prosopis glandulosa) woodland, denser in the northern part than in the east and west. The southern part of the ranch was in the foothills of the Sierra de En Medio. Collections of amphibians and reptiles were made in the woodland and next to a storage house and barnyard. A species of toad (Incilius debilis) was observed in an area subject to flooding. Parthenogenetic A. uniparens and A. sonorae were abundant; also observed here were the lizards Crotaphytus collaris, Sceloporus cowlesi, and Phrynosoma cornutum and the snakes Masticophis flagellum, Pithuophis catenifer, and Crotalus atrox. Atthough the large number of prairie dogs here had caused significant erosion, their presence here was one of the reasons the area became a Reserva de la Biosfera. This was also one of the few areas in Mexico where it was possible to observe bison in the wild. As in Arroyo Los Mimbres near to the town of Mata Ortiz, the Pradera de Janos was an area well known for the occupancy since 1150 by the same culture that inhabited Paquime. A past evidenced by presence of arrows and pot shards.

5. Mexico: Chihuahua: Municipality of Janos: Sierra de En Medio, plains of Janos, $31.160417^{\circ}$ N, $108.576472^{\circ}$ W, WGS 84 , 1436 m. a.s.l.

29 June 2004

Aspidoscelis uniparens (LEUBIPRO 12275-12277, 12280, 12283, 12330, 12797, $N=7$ ).

Aspidoscelis sonorae (LEUBIPRO 12274, 12278-12279, 12281-12282, $N=5$ ).

This was a site in the central part of the Sierra de En Medio (i.e., 2-3 km east of Rancho Los Nogales), though this area was quite different. The terrain consisted of course sand with a profusion of small quartz crystals and grains of about $1 \mathrm{~mm}$ in diameter. There were huge boulders in this part of the sierra which was the mouth of a small oasis-like canyon. There were medium to large green walnut trees supported by the unusual moisture level in this part of the prairie. The landscape had a yellowish appearance with vivid green vegetation among the medium to large (1-3 m diameter) boulders. Moreover, the temperature in this non-eroded area was moderate, being lower than in the rest of the prairie. Both A. uniparens and A. sonorae were abundant, here although only a few were collected. Also observed were the lizard species Urosaurus ornatus, Crotaphytus collaris, Sceloporus clarkii, and the snake species Masticophis flagellum. The Aspidoscelis here seemed warier than in other areas of the prairie, perhaps due to a greater predation (i.e., birds and M. flagellum) and/or more open terrain.

6. Mexico: Chihuahua: Municipality of Ahumada: Sample NSL-1 from Estación El Sueco, $29.906889^{\circ}$ N, $106.387528^{\circ}$ W, WGS 84, 1624 m. a.s.1.

07 July 2000

Aspidoscelis uniparens (LEUBIPRO 5744-5757, 5759-5766, 5768, 5770-5777, 5779-5782, 5784-5790, 5792-5805, $N=56$; some reassigned to UCM 61149-61163, $N=15$ ).

Aspidoscelis inornatus (LEUBIPRO 5758, 5769, 5778, 5783, 5791, $N=5$; some reassigned to UCM 61189-61190, $N=2$ ).

Estación El Sueco, once a train station, is now a gas station for buses and cars. The substrate on the west side of the building consisted of the kind of cream to white sand found in the dunes of northern Chihuahua, but here it was stabilized with dense associations of various grasses. It could be described as plains pastureland, with a dearth of shrubs, intensively utilized by cattle. The unusually large sample of $A$. uniparens came from an area of about $1-1.5 \mathrm{~km}^{2}$. Whether the contents of the collection of Aspidoscelis obtained in this grassland / pastureland, a small number of A. inornatus and a large number of A. uniparens, was more reflective of their relative abundance or a difference in their ease of capture was not determined. This grassland had a nauseating stench owing to the presence many dead rotting cattle, the basis of which remained a mystery. The general area at El Sueco was characterized by rolling hills with grasses and scattered shrubs, although at the collection site there were no shrubs. These rolling hills were interrupted by low rock-strewn mountains, especially on the east side of El Sueco. 
Walker et al.

\section{Appendix I. Continued}

7. Mexico: Chihuahua: Municipality of Buenaventura: Sample NSL-2 from Caseta Galeana, Llanos Flores Magón, $30.008306^{\circ}$ $\mathrm{N}, 107.253222^{\circ} \mathrm{W}$, WGS $84,1500 \mathrm{~m}$. a.s.1.

21 July 2002

Aspidoscelis uniparens (LEUBIPRO 9718-9724, 9731-9740, 9744-9748, 9750-9781, $N=54$ ).

This was an extensive flat area with gravelly and sandy substrate utilized by cattle. It was surrounded by low rock-strewn mountains on the north and huge sierras on the south. The area was quite disturbed by several factors, including flooding (as shown by vegetation patterns) and by cattle grazing. Humans in Chihuahua move large numbers of cattle between these kinds of flat areas. The flat portion was very productive for a super abundance of Aspidoscelis uniparens, the rocky outcrops and base of the rock-strewn mountains supported Sceloporus poinsettii. Other species observed were the lizards Cophosaurus texanus, Sceloporus cowlesi, Phrynosoma modestum, Phrynosoma cornutum, Holbrookia approximans, Gambelia wislizenii, and the snake Crotalus atrox.

8. Mexico: Chihuahua: Municipality of Casas Grandes: Subsample VSL-1 from Arroyo los Mimbres, $30.36^{\circ} \mathrm{N}, 107.96^{\circ} \mathrm{W}$ WGS 84, 1499 m. a.s.1.

03 July 2000

Aspidoscelis uniparens (LEUBIPRO 5669-5673, 5675-5683, $N=14$; one reassigned to UCM $61144, N=1$ ).

Aspidoscelis exsanguis (LEUBIPRO 5674, $N=1$ ).

On 3 July 2000, Arroyo Los Mimbres was a dry sandy / gravelly stream bed inhabited by two triploid parthenogenetic species of Aspidoscelis, including an abundance of the vividly striped form of A. uniparens reported herein. The arroyo had also been observed to have a strong flow after a heavy rain; however, the water disappeared in a few hours owing to runoff and the porous stream bed. The area was degraded and semiarid, being surrounded by grasslands with scattered shrubs. The arroyo, located between the towns of Mata Ortiz and Colonia Juárez, had a history of usuage by the Paquime people. Thus, people from Mata Ortiz dig in the dry bed seeking ancient pots or to obtain soil for pots. Mata Ortiz is famous for Paquime pots and clay handcrafts.

9. Mexico: Chihuahua: Municipality of Nuevo Casas Grandes: Subsample VSL-2 from km 10 on road from Casas Grandes to Colonia Juárez, $30.34^{\circ} \mathrm{N}, 107.85^{\circ} \mathrm{W}$, WGS 84, 1526 m. a.s.1.

03 July 2000

Aspidoscelis uniparens (LEUBIPRO 5685, 5687-5694, $N=9$; one reassigned to UCM 61146, $N=1$ ).

Aspidoscelis exsanguis (LEUBIPRO 5686, $N=1$ ).

This was a relatively undisturbed area of rocky hills next to the highway. The base of the hills supported grasses and shrubs, but the rocky hills were almost free of vegetation. The area was very easy to walk on it because there was scant vegetation. It had a gentle slope; the two species of Aspidoscelis, one being moderate numbers of the vividly striped variant of A, uniparens, were present at the base and the middle of the hill. The top of the hill, which was free of vegetation, was inhabited by the snake Crotalus lepidus.

10. Mexico: Chihuahua: Municipality of Casas Grandes: Subsample VSL-3 from $900 \mathrm{~m}$ W of gas company, Casas Grandes, $30.364944^{\circ} \mathrm{N}, 107.976278^{\circ} \mathrm{W}$, WGS $84,1533 \mathrm{~m}$. a.s.1.

04 July 2000

Aspidoscelis uniparens (LEUBIPRO 5695-5700, $N=6$; one reassigned to UCM 61147, $N=1$ ).

This was a relatively undisturbed site consisting of rocky hills and substrate about $50 \mathrm{~m}$ from the highway. No humans were observed during several visits to the site. The hills host eda good number of important shrubs such as Euphorbia antisiphilitica, mesquites, and others; the sides of the hills were difficult to traverse and were free of vegetation. The taludes or slopes on the sides of the hills were formed by medium to large $(50 \mathrm{~cm}$ to about $1.5 \mathrm{~m})$ volcanic rocks. The area where a few Aspidoscelis uniparens were collected was the flat top of the hills. This flat top was also suitable for habitation by Pituophis catenifer and Crotalus Lepidus; the latter species was also observed on the slopes. 


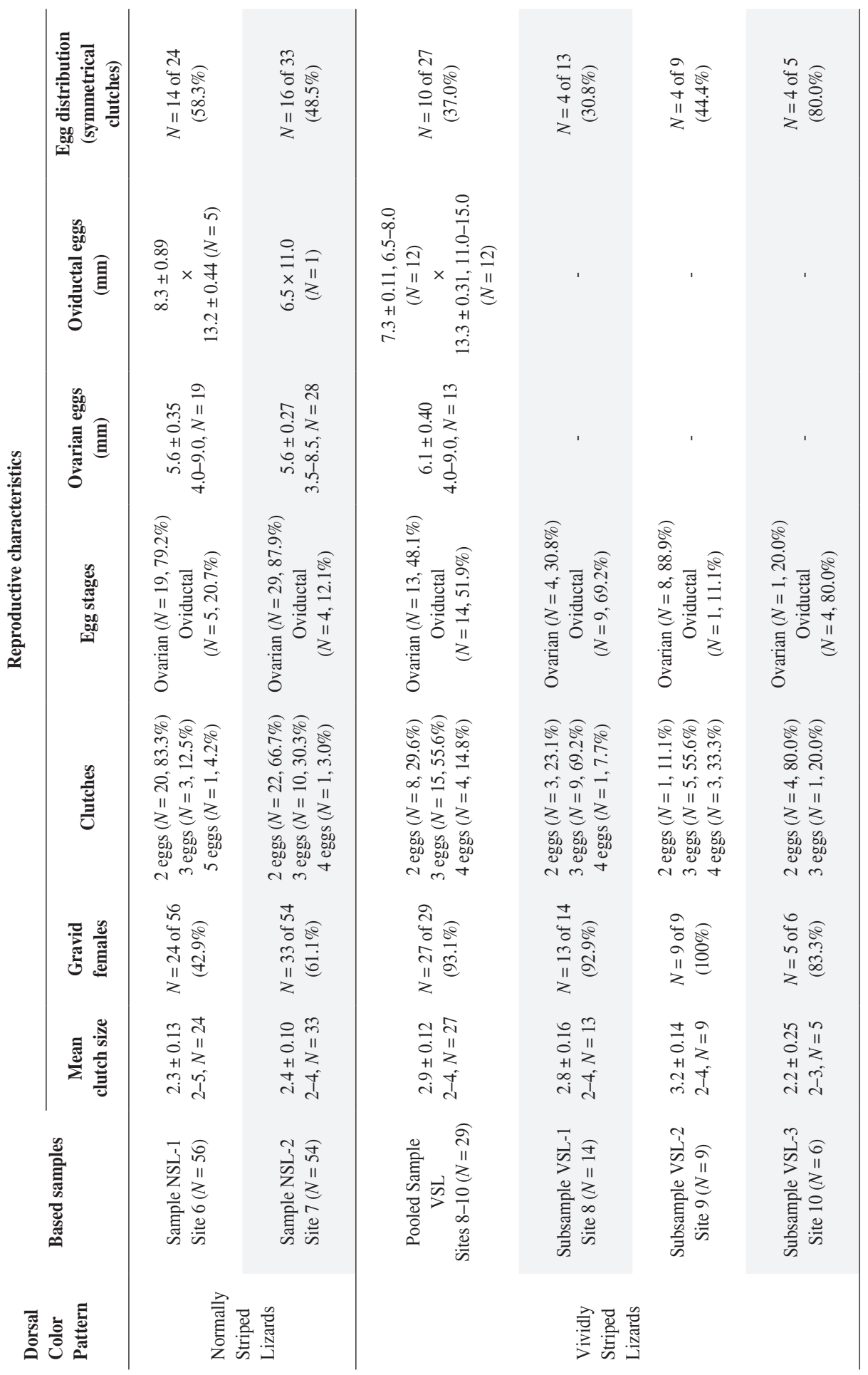

